\title{
ECT2 wt Allele
}

National Cancer Institute

\section{Source}

National Cancer Institute. ECT2 wt Allele. NCI Thesaurus. Code C101784.

Human ECT2 wild-type allele is located within 3q26.1-q26.2 and is approximately $71 \mathrm{~kb}$ in length. This allele, which encodes protein ECT2, is involved in the modulation of apoptosis, cytokinesis and signal transduction. 